\title{
Unlucky and Lucky Children, and Some Birth Superstitions
}

\section{A. J. Rose}

To cite this article: A. J. Rose (1902) Unlucky and Lucky Children, and Some Birth Superstitions, Folklore, 13:3, 278-280, DOI: 10.1080/0015587X.1902.9719312

To link to this article: https://doi.org/10.1080/0015587X.1902.9719312

Published online: 06 Feb 2012.

Submit your article to this journal $\square$

ЏII Article views: 2

Q View related articles $\square$ 
shrine, nailed her hair to the tree, and then cut it from her head. The woman was free then, and the hair remained there. On the third day they resurrected the Madu Sami doll, and peace reigned as before. This was done after the rice-harvest was over. Mooniandi Sami is always propitiated by a sacrifice or thank-offering or scapegoat. They say : "Here, devil, is your pottion, or sacrifice, now leave us alone, you have had your share."

$$
\begin{aligned}
& \text { Belgravia, Talawakelle, } \\
& \text { 23rd March, I902. }
\end{aligned}
$$

R. J. DRUMMOND.

\section{UnluCky AND JuCky ChILdREN, AND SOME BIRTH SUPERSTITIONS.}

$$
\text { (Supra, pp. 63, 188, 197.) }
$$

The Frrst-Born.-In the Punjab the first-born son of a wife is peculiarly uncanny, especially subject to magical influences and endowed with supernatural powers. On the one hand his hair is useful in witchcraft, and on the other its possession would give a wizard power over him. He himself possesses considerable magical powers, for he can stop hail by throwing a stone backwards from, or by cutting a hailstone with, a knife; and he can stay a dust storm by standing naked in front of it. He is also peculiarly subject to lightning, and is not allowed to go out on a rainy day. Snakes also become torpid in his presence. (Fuller notes on this or similar ideas would be welcome.)

A first-born child, whether a boy or a girl, should not bo married in Jeth ${ }^{2}$ (or, one account adds, in Măgh), nor should the mother eat first-fruits in that month, because as she devours them so too will the fates devour her first-born. The position of the first-born is probably due to the fact that, if a son, his father is born again in him, so that the father is supposed to die at his

1 But according to tho Matha.KTatra Cranth, sloka 15 , of Bhardwaj Rikhl, It is only necessary to avoid marriage in Jeth, if both parties be Jethas, ie., horn in Jeth, or if it is not possible to avold Jeth the ceremony should not be held in the Kirt Nackshatra during that month. 
birth; and in certain Khatri sections, e.g., the Kochhar, ${ }^{1}$ his funeral rites are actually performed in the fifth month of the mother's pregnancy. Probably herein lies an explanation of the $d e v-k d j$, or divine nuptials, a ceremony which consists in a formal re-marriage of the parents after the birth of their first son. The wife leaves her husband's house and goes, not to her parents' house, but to the house of a relative, whence she is brought back like a bride. This custom prevails among the Khanna, Kapur, Malhotra, Kakar, and Chopra, the highest sections of the Hindu Khatris. ${ }^{3}$

These ideas are an almost logical outcome of the doctrine of the metempsychosis, and it inevitably results that if the first-born be a girl she is peculiarly ill-omened.

Twiss.-There appear to be no superstitions in the Punjab connected with twins (dulld or jonkri); but in one part of the Kangra district the child born after twins is called laukka or "little."

The Sequence of Births.-There is little to be added to the notes already given (pp. $6_{3}, 68$ ), but the following details may be of interest. In Kangra a child of one sex born after two of the other sex is called trelar, ${ }^{4}$ and with that primitive confusion of thought which makes no distinction between that which is holy and that which is accursed, we have the proverb: "Trelar rele ya sangele," i.e., "a trelar either brings evil or good fortune."

In the same district a child of one sex born after three of the other is called cholar, and is, especially if a boy, propitious. As such he is presumably an object of jealousy to the fates, and his nose is drilled, like a girl, or he is given away to a low-caste man (a Barar or a Chuhra), from whom the child is redeemed by the parents by paying money or grain.

- According to one account, a Kochhar wife in the sixth month of her pregnancy pretends to be displeased and goes away from her home. Iler hushand shaves his head, beard, \&c., and goes after her with a few men of his brotherhood. On finding her, he entreats her to return and promises her a present of jewellery, whereupon she consents to come back home.

- Should a wife bear twenty children (1), she must also be remarried to her husband. The ceremony of remarringe is precisely the same as that of a first marriage, but it is perfurmed on the roof of the house.

- The Mohammedan Gadhiok Sheikhs of Jhelum also retain it. It costs about half as much as a real marriage.

Trok=a third ploughing i Jukes, Western Sunjabi Dictionary, s.e. 
The Pokhi.-(i.) Of three male children born one after the other, the middle one is said to be lucky. Of three successive female children the middle one is considered unlucky.

(ii.) A boy following and preceding a girl is regarded as inauspicious. A girl following and preceding a boy is believed to be lucky.

$\Lambda \mathrm{n}$ inauspicious child is termed bhdrd-pokhí-wdld, while an auspicious one is called halka-pokhi-zvdld. When a woman commences to grind wheat, to spin, or to churn milk she will not allow one of the former to stand by her, because she believes that the presence of such a child will render the work difficult or impossible. She will either send him away or ignore his presence. On the other hand, the presence of one of the latter children is considered a good omen, and women believe that their work will be easily finished, if such a child be sitting by them.

Birth Superstitions. - There are some curious customs connected with births at particular times or after certain periods. For instance, a child born in the month of Bhadon is lucky (unlike a calf), while one born in Katik is inauspicious. In the latter case it is considered sinful to keep the mother in the house, and she should be expelled from it, but instead she may be made over, temporarily, to a Brahman and afterwards redeemed from him.

"According to the Shāstras" a wife who has no child for some years is called sundh; one who does not bear a child for ten years, kai budhia ; and after twenty-one or twenty-four years, sut budhia. If then she bears a child, a fire of dried cowdung is burnt in front of the house, and the woman is sent away out of the village to live for forty days (a period called the parsiut) in a thatched hut, after which Brahmans are fed and she is allowed to return.

3oth June, 1902.
A. J. Rose.

\section{An Indian Ghost Story.}

The following account was given to me some years ago by Baba Akhaya Mohana, a respectable Bengali, at that time

'Pokhun in Multani $=$ an omen or augury; Jukes, Western Punjasi Dictionary, s.n. 